\title{
Teresina: a Capital sonhada do Brasil Oitocentista ${ }^{1}$
}

\section{Teresina: Dreamed capital of Brazil in the nineteenth-century}

Gercinair Silvério GANDARA*

Resumo: O surgimento da cidade Teresina foi fruto de interesses políticos e econômicos ao reivindicarem a modernidade e o desenvolvimento para o Estado do Piauí. Essa cidade nos fornece traços de um projeto moderno em sua morfologia, capazes de expressarem os anseios explicitados nos discursos do "progresso". O transporte é um dos pilares do seu nascedouro e contribui para a formação do padrão específico da vida citadina. Essa tendência fez sua inscrição no processo de “expansão”, de “modernização”, de “modernidade”, de “progresso”, enfim em sua dimensão histórica.

Palavras-chave: História. Cidade. Modernidade. Piauí. Rio Parnaíba.

Abstract: The rise of the city of Teresina was the result of political and economic interests demanding modernity and development for the State of Piaui. The city comprises many features of a truly modern project in its configuration, expressing explicit aspirations for a discourse on "progress". Transportation is one of the pillars of its conception, and it contributed to the formation of a specific standard of urban life. These developments made their mark on the processes of "expansion", "modernization" and "progress", in other words: its historical dimension.

Keywords: History. City. Modernity. Piauí. Parnaiba River.

Nos primeiros anos de 1850 nascia, em pleno vale do rio Parnaíba, a cidade de Teresina. Destinada a se tornar sede do poder político e administrativo do Piauí, ia suplantar a cidade de Oeiras, que até então exercia esse papel. No Piauí, desde a colônia, havia uma corrente insatisfação

\footnotetext{
* Pós-Doutoranda PNPD/CAPES/UFG. Doutora em História Social pela Universidade de Brasília(2008). Docente Efetiva da Universidade Estadual de Goiás,Unidade Universitária Pires do Rio. Rua Augusto Monteiro de Godoy, $\mathrm{n}^{\circ}$ 56, Centro, 75200-000 - Pires do Rio, GO - Brasil, Telefone: (064) 34612267 E-mail: gercinair@msn.com
} 
em relação à localização da capital - encravada no sertão - somada às dificuldades de transportes e comunicação. Assim, as condições financeiras, a situação de isolamento, de atraso entre outros, determinavam o ritmo das ideias e ações de seus governantes. As interpretações historiográficas regionais, os documentos oficiais, os relatos dos presidentes da Província são unânimes ao apontarem as representações de isolamento, dispersão, dissociabilidade, decadência, pobreza, atraso, estagnação, para definir sua historicidade. E os viajantes, memorialistas, historiadores etc., comumente sedimentavam tais representações.

Essas representações atuavam como testemunhos, nos quais se argumentavam sobre os inconvenientes de uma Província marcada por distâncias consideráveis somado às dificuldades de transportes para escoamento das riquezas e a localização da capital situada distante dos grandes rios. Havia argumentações, também, a respeito de Oeiras, de que não tinha condições de desempenhar um papel ativo como polo de desenvolvimento do Estado, além disso, seu “isolamento” físico trazia dúvidas até mesmo quanto à sua eficácia puramente administrativa. Em relação às condições sociais da cidade, havia alegações de não ter características de um centro urbano, pois não apresentava condições sociais de cidade e capital, embora fosse o centro das decisões político-administrativas. Alegações das mais diversas eram manifestadas, tanto pelos governos provinciais como por viajantes, e até mesmo pela própria sociedade piauiense. ${ }^{2}$

Foram, portanto, tais convicções que alicerçaram as discussões em torno das políticas públicas locais no Piauí, das quais se inserem a transferência da capital. Para sedimentá-las, Presidente da Província se valeu de estratégias políticas e das representações, com o intuito de invocar a transferência da capital e os meios de transportes aquíferos, sob os quais tentaram representar um novo tempo baseado no encurtamento das distâncias, no desenvolvimento das comunicações, no desenvolvimento local, enfim, no arsenal de transformações pelo qual se passava o país à época.

Não poderíamos deixar de evidenciar que as representações foram substituídas por outra gama de representações, tais como, progresso, expansão, crescimento, modernidade. Chegar à teia de representações articuladas em torno da transferência da capital de Oeiras para Teresina é conseguir ver, na contramão da história, que a própria noção de modernidade está informada por um contexto de simbolização do espaço como lugar híbrido. Lugar de imensas possibilidades e identificação, lugar do novo e da inovação, local do encontro de mundos. Sabemos que, ao se tentar mudar de um lugar em busca de um estilo de vida mais satisfatório, em termos de localização, de comunicação e de economia tende-se a buscar as fronteiras que, por sua vez, configuram-se também em lugar venturoso, de futuro promissor. ${ }^{3}$ Antecipamos dizer que, a partir da efetiva transferência da capital, a província do Piaú abriu-se para novas fronteiras, dado sua estratégica 
posição geográfica, e pelas condições oferecidas, tornou-se o ponto principal de convergência política, econômica e social da Província.

Particularmente, entendemos que a transferência da capital para beira-rio Parnaíba resultou de um processo mudancista que se iniciou no período Colonial. Processo este, unanimemente justificado, político e socialmente, no fato de que o futuro da província se encontrava às margens do rio Parnaíba, região destinada a ser um polo econômico e que "viria resolver o problema crônico do território [...] a dificuldade de comunicação e, portanto o isolamento que Oeiras submetia a região”. (BONFIM E SANTOS JÚNIOR: 1995, p.48). A justificativa básica para sua efetivação foi econômica, com a certeza de que a futura capital abriria espaço para a agricultura de exportação e promoveria a navegação a vapor. Neste "movimento político” havia grupos que pleiteavam o melhoramento das estradas e a implantação da navegação a vapor no rio Parnaíba e outros que defendiam a mudança da capital como meio para levar aquela Província à prosperidade. Estes acreditavam que só a transferência da capital viabilizaria a prosperidade da Província, inclusive produziria, por sua conseqüência, a navegação a vapor no rio Parnaíba, enquanto aqueles, muitas vezes, alegavam inexequibilidade e/ou dispêndios em relação à mudança da capital.

A ideia de transferência dos foros de capital, como já apontamos, remonta-se ao período colonial. Do que pudemos verificar nos documentos oficiais, a ideia de mudança da capital foi cogitada, provavelmente, pela primeira vez, em 1793, quando o Governador e Capitão-Mor das Capitanias do Maranhão e Piauí, Dom Fernando Antônio de Noronha propôs ao rei sua mudança para as margens do rio Parnaíba. Dom João de Amorim Pereira ${ }^{4}$ também propôs a mudança da capital sugerindo sua transferência para a Vila de São João da Parnaíba ou para uma recente povoação situada na embocadura do rio Poti. Contudo ${ }^{5}$ solicitou ao ministro que providenciasse e decidisse a mudança de residência dos governadores para a vila de Parnaíba. Porém, este governador não conseguiu levar a efeito seu intento. Como se vê foi em fins do período colonial que os presidentes da Província volveram o olhar para a região beira-rio Parnaíba. ${ }^{6}$

No início do século XIX, no governo da Junta Provisória (1812), reapareceu a ideia de mudança para a cidade de Parnaíba e, em 1816, na administração do governador Baltazar de Sousa Botelho de Vasconcelos sendo a mesma cidade o local escolhido. Nos anos seguintes, quer nas câmaras constituintes, quer na assembléia geral do Rio de Janeiro, ainda se tratou do assunto, preferindo a cidade de Parnaíba para assento da nova capital do Piaú. A ideia de mudança da capital foi novamente ventilada e abertamente prestigiada pelas influências políticas do norte da Província com o declínio político do Visconde de Parnaíba, residente em Oeiras. O presidente que o substituiu, José Idelfonso de Sousa Ramos, proclamando a impraticabilidade de continuar a capital 
da Província, em Oeiras, fez votar e sancionar uma lei ${ }^{7}$ que autorizava a mudança da capital para a margem do rio Parnaíba. Para isso, escolheu o local da confluência do riacho Mulato para recebê-la, ficando a nova cidade com o nome de Regeneração. Já a Lei n ${ }^{\circ} 191$ autorizou o presidente a empregar os meios adequados para a mudança imediata da capital, passando as repartições públicas para São Gonçalo, hoje Regeneração, às margens do rio Parnaíba, onde deviam permanecer até a edificação da nova capital. Entretanto, estas leis não foram executadas.

Zacarias de Góes e Vasconcelos (1845-1847) manifestou-se contra a execução das leis do seu antecessor, embora concordasse com a transferência e reconhecesse justas as razões tantas vezes apontadas, discordava do lugar escolhido. Para ele a capital devia estar em local salubre, aprazível, fértil, abundante de água e que oferecesse vantagens nas comunicações com toda a Província, principalmente com os pontos de seu maior comércio, assim como das Províncias vizinhas. Vasconcelos enumerou os elementos próprios de uma capital e concluiu negando que Oeiras os possuísse, ao menos em parte. Então, impugnou a mudança para a foz do riacho Mulato, alegando a incompatibilidade do lugar escolhido e os dispêndios em relação à mudança da capital. ${ }^{8}$ Seu sucessor, o Presidente Marcos Antonio de Macedo (1847-1848) defendia a implantação da navegação alegando inexequibilidade e/ou dispêndios em relação à transferência da capital. ${ }^{9}$ Já Anselmo Francisco Peretti (1848-1849) ao assumir o governo da Província relatou “[...] que era do mais alto interesse a navegação do Parnaíba não só para o Piaú como ainda para as províncias limítrofes, o Maranhão e o Ceará...[...]”. (Ofício nº 209 de 09.03.1849). No entanto, uma terceira Lei $^{10}$ foi sancionada por este Presidente, autorizando que se fizesse a mudança da capital para o local destinado à nova sede do município do Poti. E por resolução ${ }^{11}$, anulou-se todas as leis votadas até aquela data sobre a transferência da capital. Tal ideia permaneceu adormecida, sendo acordada ora e/ou outra nos discursos, até que em 1851 se consolidou pautada num projeto político que trazia em seu bojo a "utopia” do desenvolvimento e da modernidade. ${ }^{12}$

Inicialmente, o presidente José Antônio Saraiva ${ }^{13}$ (1850) considerou de incalculável vantagem a exploração do rio Parnaíba. Explicou que “[...] só a cidade de Parnaíba e a Vila do Poti dele se servem com a navegação pequena que existe, por se acharem colocadas em suas margens”. Relacionou os municípios que se aproveitariam e os que não se aproveitariam dessa navegação e preconizou o surgimento de novas povoações à beira do rio. Salientou ainda, que, “[...] indiretamente, porém, toda a Província ganharia”. Por fim formulou as prioridades da sua administração de acordo com as ideias que havia emitido enfatizando “[...] proteger, sobretudo as povoações da margem do Parnaíba, mudar para si as que puderem ser mudadas e preparar o terreno para que meus sucessores possam realizar um dia a mudança da capital, tão fértil em bons resultados para a Província e o Império” ${ }^{14}$ [grifos nossos]. Posteriormente, ele próprio, optou em 
promover a mudança da capital, justificando que a mesma haveria de produzir a navegação do rio Parnaíba. Antecedemo-nos em dizer que a mudança da capital provocou transformações sócioespaciais no Estado como um todo, uma vez que mudou o eixo das relações sociais e econômicas situadas no interior e no sul do estado para o norte, à beira-rio Parnaíba.

Conforme a literatura piauiense, a questão da mudança da capital se colocou logo nos primeiros meses da administração do presidente Saraiva, quando recebeu um memorial ${ }^{15}$ assinado por um número de moradores das vilas de Parnaíba, Piracuruca e a Câmara Municipal de Campo Maior no qual tratavam das vantagens sobre a já pleiteada mudança da capital. José Antonio Saraiva, tornou-se partidário da mudança, estudou o assunto e empreendeu uma viagem à vila velha do Poti. ${ }^{16}$ Lá compreendeu que a vila não podia florescer, pois estava sujeita a febres endêmicas e a periódicas enchentes do rio Poti, que a arruinava constantemente. ${ }^{17}$

Analisando a documentação e confrontando suas datas, notamos, contudo, que este presidente ao assumir a presidência já tinha como propósito esta transferência. Pe. Melo (1995, p.124) comunga dessa assertiva ao dizer que “[...] o comportamento do presidente faz pensar que a Corte já tinha conhecimento de seus propósitos, pois já em fins do mês seguinte ao da posse estava viajando para a Barra do Poti, com vistas a um exame 'in loco' das condições da vila, pois tinha conhecimento de que era insalubre e sujeita a enchentes”. Saraiva recebeu o mencionado memorial a 19.12.1850 enquanto que no ofício enviado ao conselheiro de estado Visconde de Monte Alegre, menciona o dia 22.10.1850 como sendo o primeiro dia da sua viagem aos municípios com vistas a um exame "in loco": "No primeiro dia da viagem, 22.10, examinei com atenção alguns lugares das margens do Canindé...[...]”. Neste ofício mencionou e descreveu as condições da Vila São Gonçalo, lamentando a falta de uma matriz. ${ }^{18}$

\section{Teresina: do sonho à realidade}

Para instalar a nova capital, Saraiva escolheu o local da Vila do Poti, outrora uma fazenda de gado conhecida por Chapada do Corisco. Este foi seu primeiro ato fundador. Para o historiador Laurent Vidal “[...] o primeiro cuidado do fundador é o de escolher o lugar da cidade nova”. (2009, p.245) Esta localidade, apesar de já ter sido cogitada e até escolhida, posto que, em seguida tivesse sido anulada a escolha, imprimiu um prolongado debate.

A esse respeito Monsenhor Chaves informa que as constantes enchentes que atormentavam a localidade da Vila do Poti (1987, p.13) foram “objeto de preocupação dos governos”. De fato, foi em razão das inundações calamitosas que lhe acometia nos invernos rigorosos que o governo 
central autorizou ${ }^{19}$ os potienses a mudarem o lugar da sua vila, o que foi recusado. Sobre esta lei disse o presidente Saraiva que foi letra morta porque,

[...] meio algum foi empregado para se obter semelhante resultado e entregue a mudança a ação dos interesses individuais, estes não foram tão fortes que a resolvessem sem nenhum concurso das administrações convencidas da inexequibilidade de uma mudança para cuja realização não possuía grandes quantias. (Oficio de 20.12.1850).

Explicou que chegando a Vila Velha do Poti compreendeu que não podia aquela Vila florescer e que seus habitantes desejavam com ansiedade edificá-la em qualquer outro lugar que pudesse convir aos seus interesses. “Aproveitei esses desejos, convidei-os a edificar no mais belo e agradável lugar as margem do Parnaíba...". Como a Lei nº 140 não fora executada, mas também não fora revogada, o presidente Saraiva estrategicamente nela amparado, solicitou aos potienses a mudança da vila para um local mais apropriado. Convidou-os a edificarem suas casas sob seu planejamento e em local previamente por ele escolhido, à beira-rio Parnaíba. Prometeu-lhes ajuda e ainda se comprometeu em transferir a capital para a Nova Vila Poti. ${ }^{20}$.

Todos os interesses convergem para essa mudança e foi a esses interesses que falei, encaminhei e traduzi em realidades, dando-lhes direção por meio da confecção da Matriz, do empenho que mostrei na mudança e da declaração muito formal que fiz de que, devendo em pouco tempo estarem feitas algumas casas ali, eu executarei logo a lei, ordenando para lá a mudança da justiça e do destacamento. [...] (Oficio de 20.12.1851).

Este presidente prometia uma obra excepcional que só caberia dentro de um contexto muito particular. Sabe-se que a apresentação de uma obra de tamanha envergadura como superação das contradições do passado reforçava as causas a muito defendidas e contribuíria para o progresso da renovação. A solução radical da criação ofereceria muitos atrativos. Resultaria aí, talvez, um modelo de cidade que privilegiava a comunicação, que abraçava valores tradicionais e que aspirava à reintegração o Estado. Este presidente sabia que um resultado destes só poderia ser obtido mediante uma organização aprimorada, um esforço maciço concentrado no objetivo a ser atingido, uma energia individual e coletiva constante. Conquanto, certo de suas convicções, iniciou no local a construção de uma igreja, destinada à Matriz $^{21}$, por meio de subscrições populares. Como ele mesmo disse,

Profundamente convencido da necessidade da mudança da vila comecei uma subscrição para uma matriz no novo local e no dia em que a abri excedeu de três contos de réis e continua sob a direção de uma comissão que para a promover 
nomeei. Imediatamente que isto fiz as pessoas más gradas do Município começaram a tomar terreno para edificar suas moradias e me afirmaram que em menos de ano teriam no novo local suas casas, que serão regularizadas de modo que a Vila, cuja planta remeto a V.Excia ofereça um aspecto agradável a todas as comodidades que sua bela e conveniente situação permite. (Oficio de 20.12.1851).

Destarte o “criador/fundador” repetia o processo das primeiras nucleações paroquiais, em que a igreja foi o marco referencial para o surgimento de cidades. No Brasil, a construção e a inauguração de uma capela/Igreja constituíram-se em importante vetor de indução para o surgimento/povoamento de um determinado lugar. Assim sendo, vale dizer “como o príncipe imperial, Teresina, nasceu nos braços da Igreja Católica, isto é, na celebração de uma missa, na hora em que se lançava a pedra fundamental de sua matriz, a Igreja de Nossa Senhora do Amparo”. (SILVA FILHO: 2007, p.95), Foi assim que à beira-rio Parnaíba, se ensaiou um estabelecimento único, excepcional, com ideias e conveniências, visão estratégica e atrevimento comum de um "bandeirante”22 se cristalizou. Como disse Cassiano Ricardo (1959, p.303) “[...] quem pratica 'atos de bandeirismo' pode ser chamada 'bandeirante', a palavra 'bandeirante' toma um sentido mais amplo; é sinônimo de pioneiro, de sertanista, de 'grande empreendedor: é o que funda cidades [...]”. E Laurent Vidal (2009, p.243) reforçou dizendo que “[...] toda fundação de uma cidade é uma ocasião de reescritura do grupo fundador ou da nação, segundo a importância e a função exercida pela cidade no conjunto do território nacional. A cidade nova inscreve-se na história à medida que a mesma apresenta-se como o ponto de partida de uma nova história”.

Saraiva, em contrapartida, conseguiu com sua presença e suas convicções despertar o interesse dos potienses para o novo e, talvez, arriscado empreendimento. Estes, por sua vez, lançaram mão dos seus capitais, iniciando, imediatamente, o desmatamento da vegetação que cobria a vasta planície. Saraiva também se mostrava animado e convencido de que as promessas por parte dos potienses seriam cumpridas relatando “[...] em verdade tenho todas as razões para crer na sinceridade de semelhantes promessas porque elas exprimem interesses e necessidades sentidas” (Oficio de 20.12.1851).

A transferência de uma capital é um assunto deveras complicado e dispendioso, exige uma boa quantidade de habilidade organizacional e envolve níveis do governo, nacional, estadual, assim como local. Mas o progresso substancial pode ser realizado, desde que a comunidade, trabalhando junto com as autoridades, participe dos objetivos. É óbvio que, na transferência da capital de Oeiras para a Vila Nova do Poti, houve muitas decisões cívicas governamentais. Todavia, não tínhamos consciência, mesmo de modo desarticulado, das nuanças e sutilezas que antecediam tal escolha. Conquanto, entreviu-nos que razões econômicas estimulam a especialização de grandes empreendimentos. Em verdade, a preferência de instalar a capital em 
terras da Vila do Poti tinha razões evidentes. Acontece que esta vila, situada na confluência do rio Poti com o rio Parnaíba foi, ao longo dos primeiros séculos, a única passagem entre o norte da Capitania e o restante do Brasil. A apregoada dificuldade de comunicação de Oeiras obrigava o escoamento somente pelo Maranhão, justamente nesta passagem. Era, então, por este local que se fazia o escoamento das riquezas do Piauí. Condição que se tornou argumento pró-mudancista.

Além de tudo isso, a escolha da posição para edificar a nova cidade, se deu em lugar estratégico. ${ }^{23}$ Estava situada quase no centro geográfico da unidade federativa de que iria se tornar a sede e, em todo caso, no lugar que se destinava a um grande futuro, pelo fato de margear o rio Parnaíba, via líquida que dividia todo Estado e que apresentava vantagens seguras aos intentos de fazer dele uma estrada líquida fluída. A navegação a vapor seria quem provocaria o despertar do lugar. Tanto que o presidente Saraiva opinou à Assembleia Provincial ${ }^{24}$, “[...] é mister, portanto, que eu e vós, senhores, estejamos à margem daquele rio, e não vivamos a dezenas de léguas, nestes sertões, uma vida estéril para os mais importantes melhoramentos materiais da Província [...]”. Nesta ocasião, Saraiva apresentou as vantagens da mudança da capital para a Vila Nova, que se localizava próxima as ricas matas, banhadas por um dos melhores rios do Brasil, “[...] salubridade, capacidade para arrebatar a Caxias o comércio do Piauí, facilidades para as relações comerciais e políticas com a Corte e os grandes centros do Império, mais rica zona agrícola da Província, e, portanto maiores possibilidades para o progresso[...]”. (Fala de 03.07.1851). E apontou suas razões em preferir aquela localidade para sede do Governo enumerando,

$1^{\circ}$ porque é ela bem situada e a mais salubre que é possível;

$2^{\circ}$ porque fica na posição de tirar a Caxias todo o seu comercio com o Piauí, conseguindo-se assim a maior vantagem da mudança;

$3^{\circ}$ porque, mais próxima da cidade de Parnaíba, pode servir melhor ao desenvolvimento da navegação e gozar a Capital do grande benefício da facilidade de suas relações políticas e comerciais com a Corte, e de todos os grandes centros de civilização do Império;

$4^{\mathrm{o}}$ porque fica no município mais agrícola da Província e é preciso que o governo cuide seriamente de promover o aumento de sua agricultura, o melhoramento dos processos de que ela usa e dar a conveniente direção a seus produtos;

$5^{\circ}$ porque é aquela localidade a única que promete florescer a margem do Parnaíba e habilitar-se em menos tempo para possuir a Capital da Província. São estas as razões que tenho para recomendar-vos a nova Vila do Poti as honras de sede do Governo da Província. (Relatório da Sessão Ordinária de 03.07.1851).

Notamos, então, que a posição escolhida, em pleno vale do rio Parnaíba, foi ditada por considerações práticas imediatas e demonstrava o franco interesse em unificar um território díspar. A comicidade estratégica da localização tinha todos os fatores para se transformar numa encruzilhada de vias de comunicação. E a nova cidade sediando a capital promoveria, ela mesma, 
novos fenômenos, tornando-se não um ponto de chegada, mas um ponto de partida. A precisão da escolha do local/região para instalar a capital teria reflexos importantes para toda a província através dos tempos. As suas qualidades eram as beira-rios e as caprichosas cabeceiras da bacia. Dessa construção resultaria a total transformação da paisagem. Em uma palavra, a solução da sua posição às margens do navegável rio Parnaíba era absolutamente feliz, pois além de receber a capital propiciaria uma transição. Condição e argumento pró-mudancista, pois, uma vez estabelecida a capital às margens do rio Parnaíba, as comunicações seriam amplamente favorecidas e, conseqüentemente as ações econômicas, sociais e administrativas.

Em contrapartida, os obstáculos a superar eram imensos. Indiscutivelmente era preciso coragem, energia e entusiasmo para ousar enfrentá-los. Para ser bem-sucedido era necessário também, certo cuidado e uma grande capacidade para convencer. Nenhuma dessas qualidades faltou ao jovem presidente, cuja ação pioneira merece ser destacada. O espírito do pioneiro que veio para conquistar um “mundo novo” estava disposto a vencer os obstáculos e a constituir um triunfo considerável, ao qual se associava o fato de estar a opinião pública naturalmente inclinada a apoiálo. A sinceridade das ideias expostas, a simplicidade das fórmulas propostas e, sobretudo, o espírito sistemático que presidira a elaboração do projeto estavam aptos a responder à ânsia de piauienses que há algum tempo vinha se alimentando de esperanças frustradas em decorrência dos vários discursos de inexeqüibilidade. Contra essas constantes alegações, rebateu o presidente Saraiva ${ }^{25}$ enfatizando a alta conveniência da mudança da Capital para a Vila Poti e explicando que a responsabilidade administrativa de um governante devia ser mais importante que as preocupações com despesas.

[...] creio haver mostrado... sobre não ser inexeqüível semelhante mudança e pode o governo lucrar... Desejaria mostrar a V.Excia. o quanto deve lucrar a navegação do Parnaíba com a mudança da Capital para aquela localidade. [...] “... desejaria inteirar a V.Excia. de todas as circunstancias que criaram em mim uma convicção tão forte a respeito da necessidade da mudança da sede do governo, hoje reconhecida exeqüível... (Fala de 03.07.1851).

Com tudo muito bem encaminhado na Chapada do Corisco, inclusive a construção de prédios em ritmo acelerado e em ordem de arruamento, conforme planejado - e os potienses, entusiasmados e encorajados, pela certeza de receberem em breve a nova capital do Piauí - o presidente regressou a Oeiras. Lá se encontrava o maior obstáculo a superar, uma vez que a comunidade oeirense reagia a qualquer ideia de mudança. Havia, entre os políticos locais, aqueles que “[...] defendia a tese de que o progresso viria com a mudança da capital e os opositores que pleiteavam o melhoramento das estradas e o aproveitamento do rio Parnaíba como recursos 
principais para a solução do problema”. (NUNES, 1974, p.106). Contudo, usando de seu prestígio, Saraiva buscou influenciar os deputados da Assembleia que, na sua maioria, tinham sido favoráveis à permanência do Governo em Oeiras. Mas, mesmo conhecendo o pensamento da maioria do Legislativo, foi muito incisivo em sua fala ${ }^{26}$, na qual tratou pormenorizadamente do assunto da mudança da capital, discutindo as vantagens do local escolhido, considerando-o de ótima situação topográfica de par com recursos certos e futuro promissor.

Assim, Saraiva teceu longas considerações sobre o lugar e suas vantagens, enfatizando: “Filhos da Província sabeis da viagem que empreendi aos municípios do norte, para examinar e verificar a navegabilidade do Parnaíba, e possibilidade de dar impulso em suas margens a uma povoação que própria fosse para o mister assento do Governo da Província”. E continuou relatando: “[...] dizer-vos, senhores, que a margem do Parnaíba e a uma légua da Vila do Poti se levanta e cresce uma pequena povoação é resumir a série de fatos...” Salientou, ainda, “[...] tenho-vos, mostrado que podeis resolver, em harmonia com os recursos da Província, o grande problema do seu engrandecimento; convém, porém, mostrar-vos ainda a razão da preferência que dou aquela localidade para assento do Governo da Província...”. (Fala de 03.07.1851).

Este intento exigia, também, recursos que superavam em muito os das coletividades locais. Por essas razões e dadas às condições particulares do país e do Estado, uma tentativa dessas só poderia ocorrer dentro de uma política de prestígio que envolvesse governo e sociedade. Destarte, sabemos que toda essa transformação/mudança incluía objetivos claros e articulados aos projetos do governo imperial. Podemos, inclusive, associar sua existência aos planos do império sob a ordem do $\mathrm{rei}^{27}$. Sabemos, também, que o poder imperial, no Brasil, se constituiu com bases voltadas à centralização das ações políticas do país na figura do imperador. As províncias eram governadas por indivíduos de estreita confiança do imperador, indicados por critérios ligados as suas carreiras políticas individuais. Como observa Santana (1965, p.40). “[...] ao institucionalizar-se o poder, em 1845, no Piauí, o Império se fazia presente através de seus representantes no governo provincial. [...] os políticos piauienses mais representativos discutem os problemas locais dentro de perspectivas eminentemente nacional” Para este autor a realidade piauiense é um componente da realidade nacional.

Vale dizer, portanto, que a atuação do Conselheiro José Antonio Saraiva configura-se num exemplo da política do poder imperial ${ }^{28}$, uma vez que foi nomeado por efeito da Carta Imperial a Presidente da Província do Piauí, em 19.06.1850. Retomando a fala do presidente Saraiva, logo após tecer longas considerações sobre o lugar e suas vantagens, sobre a navegabilidade do rio Parnaíba e detalhar as providências e planos para sua implantação falou textualmente aos contrários ao empreendimento. ${ }^{29}$ 
Consta-me que alguns cidadãos desta cidade representaram ao Governo Imperial contra o sistema administrativo que hei seguido e que, para tender a preparar o terreno para mudança da Capital, ofende os interesses de Oeiras, que na opinião daqueles cidadãos tem direito de ser a sede do governo por possuir alguns edifícios públicos, por estar no centro da Província e por ser uma cidade pobre que, sem a Capital, ficaria reduzida a pouca coisa. (Fala de 03.07.1851).

Assim sendo, o presidente transferiu a decisão para os mesmos dizendo reconhecer que a mudança da Capital feria interesses, preconceitos e profetizou,

Deus queira que esses interesses produzam em vossa presença todas as razões que puderem servir para esclarecer-vos no juízo que tendes de pronunciar acerca da questão, que fica sujeita a vossa consideração. Vós decidireis se esses interesses são legítimos e pode abalançar-se a disputar a Província à vitória de suas altas conveniências, e se o futuro do Piauí deve ficar prejudicado só porque haveis despendido nesta cidade em ponte, em calçadas, em um hospital e em uma casa de liceu, algumas quantias. Vós decidireis se, por amor dessas quantias, deixará o Piauí de conquistar pelo comercio, pela agricultura, pela indústria, somas maiores que poderão em pouco tempo dar-lhe uma Capital mais rica, mais cômoda, mais civilizada e mais conveniente a direção dos negócios públicos (Fala de 03.07.1851).

Em seguida, lamentou, “[...] senhores, ninguém mais do que eu sente profundamente que alguns ilustres piauienses sofram com essa mudança da Capital”. E ultimou. “[...] deveis decidir de uma vez se é útil, exeqüível a mudança da Capital. Se aceitardes minhas convicções, deveis contar com todos os meus esforços [... ]”. Mas, consciente do pronunciamento hostil a uma parte da Assembléia, percebeu que não seria prudente, naquele momento, a passagem de uma lei que mudaria os destinos da Província. Tal situação não estava isenta de riscos, já que abria caminho para uma nova conjuntura. Não deixou, também, de ser benéfica, na medida em que permitia audaciosos projetos que se lançariam resolutamente. Destarte, para realizar seu propósito, aliás, que já não era simplesmente seu, mas de quase toda a Província que o abraçara em suas representações, ora vindas dos povos, ora das municipalidades, precisou esperar o esforço dos habitantes da Vila Nova do Poti na obra de sua edificação. Os potienses, por sua vez, voltados para o futuro, objetivando a criação da nova cidade que abrigaria a capital do Estado, não mediam esforços. Na prática, entretanto, tendo em vista a busca do "novo", do "promissor", mostraram-se influentes em prover uma orientação geral para a efetiva ocorrência do desenvolvimento local e, quiçá regional. E a resposta dos cidadãos potienses fora além das expectativas do Presidente Saraiva.

[...] O resultado de tudo isso foi além das minhas esperanças, porque nunca acreditei que, em menos de seis meses estivessem em construção perto de trinta 
habitações e, ainda mais, que os mesmos habitantes da Vila Velha, que ali tinham elegantes casas, se resolvessem a deixá-las para construir em novo local, hoje geralmente chamado Vila Nova do Poti [...] (Fala de 03.07.1851).

Instalou-se, então, nova assembleia $^{30}$ e, no dia 21.07.1852, foi baixada e promulgada a Resolução $n^{0}$. 315, que autorizou a transferência da capital para a Nova Vila do Poti, elevada desde logo à categoria de cidade, com o nome de Teresina ${ }^{31}$ e com foros de capital. O Presidente Saraiva dirigiu pessoalmente o transporte do acervo da antiga vila e instalou na nova sede a Câmara Municipal e demais repartições públicas. ${ }^{32}$ Antes, porém, de deixar a cidade de Oeiras, conforme Pe. Chaves, (1987, p.28), o presidente “[...] tomou medidas necessárias e precauções para a sua segurança individual, uma vez que, tinha sido informado de que se formava um plano de atentado contra a sua pessoa, contudo deixou assinado o decreto de mudança da capital”.

Jurandir Ferreira Pires nos relata que Saraiva foi informado de que se “[...] formava um plano de atentado contra a sua pessoa e tendo tomado as medidas necessárias e as precauções exigidas para a sua segurança individual [...] retirou-se de Oeiras. [...] Quando a bomba explodiu já o ilustre e pertinaz Presidente estava distante” (FERREIRA: 1958, p.628).

Antecedemo-nos em dizer que a realização da mudança da capital se dera à custa de frustrações, reações e pela convicção do "progresso", entendido como modernidade. Não restam dúvidas de que se tratou de uma operação audaciosa, de improvisação, que se fez às pressas numa das circunscrições mais pobres do Brasil. É certo, também, que encontrou uma oposição encarniçada por parte dos adeptos da rotina da cidade colonial. Como aponta Yves Bruand (2002, p.346), “Teresina e Aracaju tornaram-se as respectivas capitais das províncias do Piauí e Sergipe à custa de Oeiras e São Cristovão, abandonados depois de uma resistência vigorosa dos habitantes frustrados”. No caso de Teresina se o presidente Saraiva não tivesse se retirado prudentemente, em tempo de Oeiras, teria, com certeza, sido vítima de alguma agressão.

Parafraseando Ferreira (1958, p.628), os ânimos se irritaram e era um verdadeiro clamor público que os mais exaltados cobriam de injúrias e juraram tomar, mesmo no Poti, uma vingança estrondosa e sanguinária. Mas o presidente Saraiva se foi, levando a efeito a transferência, ou seja, a meta daquele presidente se cumpria animado à perspectiva de capturar o futuro "promissor" da experiência humana no tempo.

Foi lá, foi assim, foi ele, foi-se, então, a capital de Oeiras para Teresina... Para os oeirenses o “golpe” foi terrível. Para nós, a verdade do acontecido é impraticável e irrecuperável, restandonos a tarefa de construir uma narrativa verossímil, buscando se aproximar ao extremo do que teria acontecido de fato e/ou possíveis de terem acontecido, em tudo “verdadeiras” na sua ilusão referencial. Vale enfatizar, que até aqui nos interessou apresentar uma visão panorâmica do 
espectro de discursos que circundaram a questão da transferência da capital e a explicitação do diálogo atribuído a essa 'necessidade' apresentada desde fins do período colonial até a efetiva transferência da capital.

O presidente Saraiva ao chegar a Teresina tomou com rapidez todas as providências necessárias para a transferência imediata da máquina administrativa da Província. Mesmo assim, muitos oeirenses, ingenuamente acreditavam na possibilidade da volta do governo para Oeiras, por deliberação da Assembleia com a retirada do Presidente ou por ordem expressa do governo imperial. Ocorre que Saraiva deixou, todavia, de transferir o poder judiciário para Teresina, ficando a única comarca do Piauí sediada em Oeiras, até 14.12.1855. ${ }^{33}$ Como disse Pe. Chaves (1987, p. 28), “[...] todas as repartições deixaram Oeiras e se estabeleceram na nova capital nos prazos fixados por Saraiva. Ficando deserta da vida oficial a velha capital entrou em decadência que foi rápido”.

Mas um impasse ainda restava nos desdobramentos desta questão que nos conduz à busca das “verdades” possíveis sobre esse passado. Segundo Ferreira (1958, p.628) corria o boato que o povo não deixara o cofre público sair de Oeiras e “[...] os agitadores gritavam pelas ruas que a senha da revolução era essa tentativa aviltante para os oeirenses, da retirada do cofre, sinal definitivo da realização da projetada mudança”. Ainda segundo Ferreira (1958, p.28) “queriam, pois que o erário público ficasse em Oeiras, como garantia de permanência da capital e em protesto contra o Ato Presidencial”. Esta esperança conferia aos oeirenses legitimidade e identificação com a realidade do acontecimento vivido, em verdade, um finito sem limites. Mas o cofre colocado num carro puxado por bois partiu de Oeiras cercado de numerosa força armada.

A população, conforme Jurandir Ferreira (1958, p.628) “[...] desiludida, abandonada a ideia de revolta, que realmente nunca tivera, entregou-se a uma dolorosa desolação, acompanhando-o até ao lado oposto da grande ponte construída sobre o Mocha [...] Foi um dia de luto geral”. Esta observação de Ferreira, “[...] abandonada a ideia de revolta, que realmente nunca tivera”, em si, nos perturba, pois desestabiliza nossas impressões daqueles que encerram razões e sensibilidades, sobretudo neste tempo vivenciado por nós ao interrogar os piauienses sobre o outro tempo, o de meados do XIX, a fim de entendermos o contexto da transferência. Somos conscientes de que dar inteligibilidade aos sentimentos do que aconteceu por fora da experiência do vivido é tarefa difícil. No entanto estamos a representar o passado. E, se esta narrativa foi trazida para a reflexão, foi para discutir um elemento que nela comparece sem traumas: o abandono.

Sabemos que uma cidade não é percebida pelos que nela habitam, como um quadro. Sua percepção é organizada em função de uma série de laços existenciais, práticos e afetivos que nos unem a ela. Entendemos, portanto, que a obrigatoriedade dos rastros de sofrimento e indignação por 
parte dos oeirenses amplia o leque dos possíveis traumas e, talvez, lamentem até hoje. Com isso, chegamos a um fim, que é na verdade um começo e/ou um recomeço.

\section{Concretização e Efetivação do Sonho: “A cidade de Saraiva”}

O nascimento da cidade Teresina não foi apenas o efeito do livre jogo de forças ou das necessidades locais, mas sim do Estado que dirigiu e/ou induziu a transferência da capital provocando toda transformação socioespacial piauiense. Podemos dizer que este surgimento correspondeu a motivos considerados subaspecto dos motivos políticos. Foi resultado e produto do avanço do capital, das estratégias do governo em que a estrada líquida fora o meio físico para alcançar os objetivos da política em curso. Podemos dizer, também, que em seu "nascedouro" a cidade Teresina fez parte, ainda que de forma sutil, do processo de expansão das comunicações da Nação. Esta cidade traz em si a inspiração criadora da vida humana, embora tenha integrado heranças construtivas da história do Piauí e, consequentemente do Brasil. Já a transferência da capital piauiense representou o reflexo de uma época caracterizada por um complexo de inferioridade levado ao extremo, sob o ponto de vista local, mas continha o germe dos elementos de uma reação salutar e não demorou a se manifestar.

Nos primeiros dias, na nova sede, a capital sofreu as deficiências naturais de uma mudança apressada. No dia 16 do mesmo mês, o presidente José Antônio Saraiva dirigiu Circular a todos os presidentes de Província do país comunicando a transferência da capital e, conseqüentemente, sua nova residência. ${ }^{34}$ Por meio de outra Circular $^{35}$, fez nova comunicação às Províncias do país, noticiando o encerramento definitivo da mudança da capital. ${ }^{36}$ Foi assim que, nos primeiros anos da segunda metade do século XIX, o Piauí assistiu ao “[...] mais significativo deslocamento da gestão do poder das elites agrárias do centro para o norte da província do Piauí”. (NUNES E ABREU, 1995, p.97).

Os motivos e objetivos utilizados para essa transferência pouco se desviaram, dos projetos e discursos advindos desde o período colonial, pelo menos em essência. Estes discursos, em sua maioria, identificavam na navegação a vapor o elemento que provocaria um futuro promissor e uma nova ordenação econômico-espacial. Entendiam que os navios a vapor propiciariam que todas as fronteiras pudessem ser atravessadas de tal modo que todos, unidos, formassem uma terra totalmente sulcada por caminhos. E a 'nova capital' seria como uma panaceia. Em resumo “[...] a 
transferência da capital para Teresina (1852) foi um dos principais fatores para se começar um processo de desenvolvimento do Piauí, com participação ativa no comércio internacional”. (GANDARA, 2008, p.373).

Como já comentamos, o processo de mudança empreendido pelo presidente Saraiva trazia em seu âmago uma concepção inovadora dos surgimentos das cidades brasileiras, o planejamento do traçado urbano. As regras do futuro "traçado urbano" da cidade concebida para abrigar, num futuro próximo, a nova capital do Piauí, ele próprio elaborou. Em ofício ele mesmo conta e descreve seu plano,

Não me ocupo em descrever as vantagens e belezas da localidade porque V.Excia me acreditará nesse ponto sem ouvir razões, e pela planta conhecerá que a Vila se começará muito regularmente. Nessa planta fiz uma mudança que foi fazer sair na grande praça três ruas em lugar de duas, formando três quarteirões dos dois que existem na mesma planta. Os seis quarteirões da grande praça estarão ocupados por belas casas, antes do ano, porque pessoas muito abastadas vão principiar suas moradas e um desses quarteirões já tem todos os alicerces para uma grande propriedade, que seu dono promete acabar antes de seis meses. (OFICIO DE 20.12.1850...).

Ao contrário das antigas aglomerações da Província que comumente surgiam espontaneamente, a cidade de Teresina inaugurava uma regularidade planejada. O plano elaborado por Saraiva para a cidade era uma experiência interessante, de certa grandeza natural, em que ficava nítido o objetivo de criar uma cidade ordenada. A escolha da melhor situação e a inexistência de construções propiciou a elaboração de um plano racional, regular e, até mesmo, “monumental”. A planura do sítio onde se localizou a cidade Nova do Poti também contribuiu para sua ordenação espacial inicial. A sua situação e seu sítio ofereceram alguma ordenação a mais para a utilização da terra a ser edificada. O próprio lugar, com todos seus componentes se propunha como elemento de produção, como produto, como texto escrito e vivo, onde estariam fixadas e transmitidas as aquisições fundamentais e as escolhas contingentes. “O plano em grelha, as ruas bem alinhadas e ortogonais, as praças e prédios principais destacados”. (MARX, 1980, p.39). Todos esses argumentos mostraram-se decisivos. 


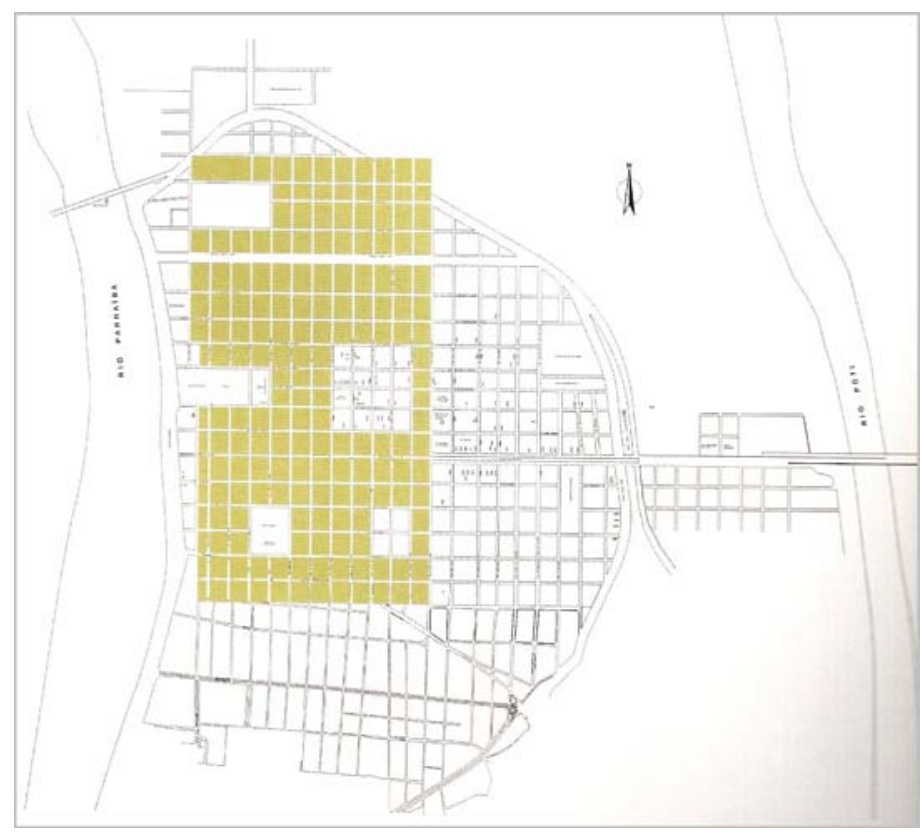

Figura 1: Sobreposição do traçado original sobre o atual.

Fonte: SILVA FILHO, Olavo P. Carnaúba, Pedra e Barro na capitania de São José do Piauhy. Belo Horizonte: Ed. Do Autor, 2007, p.108.

No plano Saraiva a regularidade geométrica, ou seja, a retilineidade foi explorada e adquiriu maior consistência com o crescimento da cidade. Nele se previa sua extensão, tendo seu ponto central na Igreja do Amparo, a partir da qual deveriam se orientar todas as outras medidas de demarcação da cidade. Da grande praça da matriz fez sair três ruas, formando três quarteirões fazendo com que os arruamentos fossem cortados em ângulos retos. Assim o traçado das ruas em linha reta, cruzando-se umas com as outras, davam a forma de um tabuleiro.

De acordo com Yves Bruand (2002, p.346) “[...] a regularidade do traçado de xadrez era uma solução que se encaixava nos hábitos brasileiros em matéria de urbanismo do século XIX, hábitos largamente prolongados até hoje”. Os seis quarteirões da grande praça seriam ocupados por casas de morada. O parcelamento das quadras se fez com a divisão das mesmas em duas metades, cada lado subdividido em cinco a seis lotes com as testadas voltadas para as ruas que descem ao rio. A acomodação das quadras seguiu a linha frontal da igreja, enquanto entre o rio e a primeira fileira de quadras se preservou uma parcela generosa de terreno o que se presume intenção de proteção ambiental em relação às enchentes do rio. Assim sendo, inovador também na concepção deste plano foi se apresentar impregnado de caráter paisagístico e ambiental ao buscar oferecer uma povoação regularizada, pois como bem disse Saraiva "na mais bella, e mais conveniente localidade às margens do rio Parnahyba, pois que o percorri em grande extensão, e não vi outro igual [...]” (Ofício de 20.12.1850...,). Conforme designação constante da Planta da Esplanada de Teresina, de 
1922 (vide figura abaixo), a cidade “[...] assentada com o flanco W junto ao Porto Carência revela um proposto cenográfico e exploração da paisagem fluvial”.

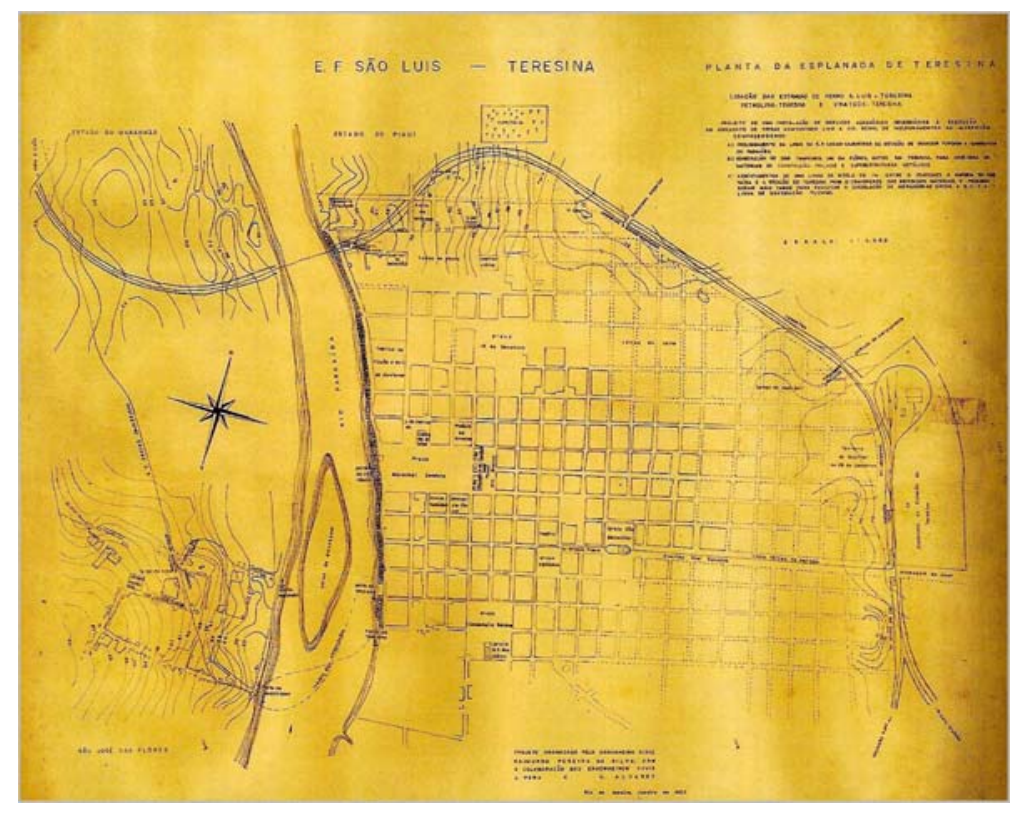

Figura 2: Planta Esplanada de Teresina.

Fonte: IPHAN-PI

De fato, o rio Parnaíba deu ao centro urbano o encanto delicado que dele emana. A cidade foi edificada em tal clima de simpatia com o rio Parnaíba que a sensibilidade do lugar e a sua própria beleza constituíram o requisito fundamental exigido. Pareceu-nos que a beleza da paisagem foi procurada como um elemento da arquitetura. A cidade ao crescer ia conquistando as águas do rio Parnaíba, a via líquida, por sua vez, correndo pelos vales profundos e apertados abraçou a cidade de forma surpreendente deixando-a envolvida por seus contornos. Essa delineação foi dada pelo rio Parnaíba, mas também pelo rio Poti, que juntos emolduraram a fascinante criação.

Essa preferência absoluta pela beira-rio explica, parcialmente, as flexibilidades do traçado adotado, onde as ruas serpenteiam para prender-se melhor ao rio Parnaíba. Com efeito, uma rua é sempre orientada para um determinado lugar, percebida como se dirigisse para algum lugar. O rio Parnaíba reforçara esta impressão de perspectiva. Sua localização foi crucial. Segundo Rossi (1995, p.141), “[...] tratando-se da origem da cidade [...] quer se trate de uma cidade espontânea ou de uma cidade deliberada, o traçado de sua planta, o desenho de suas ruas não se deve ao acaso. [...] Existe sempre um elemento gerador do plano”. E no caso de Teresina o elemento gerador foi o rio Parnaíba.

A concretização do projeto Saraiva e o resultado da retilineidade se deve, em parte, aos potienses que, obedecendo ao plano em sua severa regularidade, deram início à construção de casas, formando arruamentos cortados em ângulos retos. Em menos de seis meses foram iniciadas a 
construção de cerca de trinta habitações. Inclusive os proprietários de elegantes casas na antiga Vila do Poti, deixaram-nas para construir outras no novo local. Consoante o Padre Chaves na obra “Teresina”, nos dez primeiros anos de existência era pouco lisonjeira a situação da nova capital. Segundo ele, “[...] o emprego de trabalho escravo e de material improvisado nas construções, agravado pela falta de assistência técnica, imprimiram-lhes um estado de precariedade de que se ressentiam todas elas ao contemplar a cidade os seus primeiros dez anos de existência” (1987, p.27)

Notamos, entretanto, que esta primeira década de sua existência marcou uma efervescência notória. As repartições do governo, embora em 1852 alguns edifícios públicos já estivessem em construção, foram instaladas em casas alugadas. Vale lembrar que a presidência estava autorizada ${ }^{37}$ a obter, por aluguel ou pela forma que mais conveniente lhe parecesse, os prédios necessários para as repartições públicas. A mandar construir por administração ou por arrematação, no local da nova cidade, uma cadeia, um cemitério e quaisquer outras obras que fossem necessárias e se harmonizassem com os recursos da Província. Desse modo, a nova cidade capital poderia "exercer em plenitude a função própria de uma cidade sede de Província e promover o seu desenvolvimento” como disseram Nunes e Abreu (1995, p.95).

Por volta de 1860, Teresina já cobria uma área de mais de um quilômetro de extensão na direção norte-sul, ia do largo do Quartel do Batalhão até o "Barracão”. Na direção leste-oeste sua expansão se dava mais lentamente. Para o lado do rio Poti, as ruas findavam-se numa linha que corria irregularmente algumas dezenas de metros acima das praças da Constituição, hoje Deodoro, e o Largo do Saraiva, atual Praça Saraiva. Para o lado do Parnaíba nem todas as ruas chegavam ao rio. Evidencia-se a efervescência da primeira década de sua existência considerando os 49 habitantes, que em junho de 1851, viviam na Chapada do Corisco, local escolhido para edificação da cidade. E em 1857, a população do município de Teresina já se constituía de 11.820 hab., conforme Pe. Chaves (1987).

Por outro lado, Teresina expandiu-se rapidamente, pois, na segunda década já contava com 963 casas, das quais 433 eram cobertas por telhas e 530 cobertas de palhas. ${ }^{38}$ A iluminação pública de Teresina, que consistia apenas em lampiões às portas de algumas repartições públicas e em casas de altas autoridades, foi inaugurada em 1882 com a instalação de 80 combustores a querosene nos principais logradouros. A iluminação elétrica foi inaugurada em 1914, e o calçamento foi iniciado em 1929, na administração do então intendente Major Dr. Domingos Monteiro, que escolheu uma das principais ruas da cidade, a Rua Álvaro Mendes, para beneficiar-se do melhoramento. O calçamento era feito com pedras irregulares, cujo assentamento não obedecia ao menor gosto artístico ou técnico. Esse material foi, por longo tempo, empregado para calçamento das ruas de Teresina até que mais tarde passou a ser usado o paralelepípedo. 
Na foto abaixo, se pode observar a cidade de Teresina de 1910 e, no entorno da praça, os primeiros edifícios da cidade. Da esquerda para direita, o mercado, casas comerciais, um sobrado residencial cedido para o Palácio do Governo. Na cabeceira da praça, o Fórum e a matriz de Nossa Senhora do Amparo.

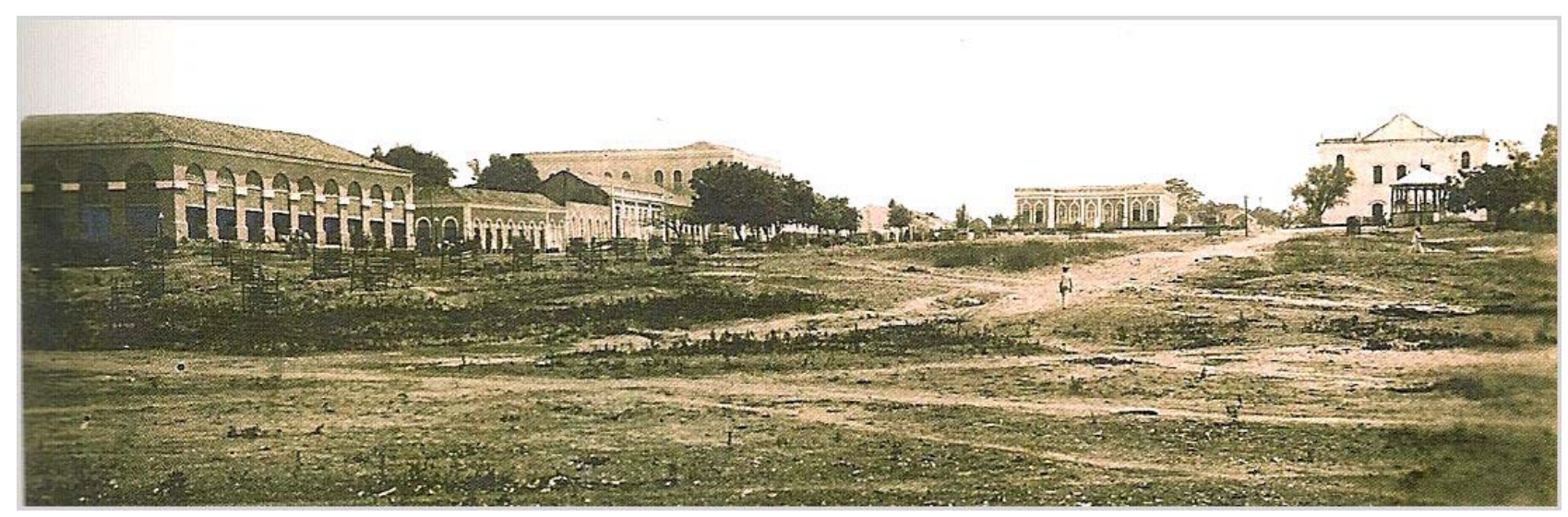

Figura 3: Praça da Constituição. Foto de1910, autor desconhecido.

Fonte: SILVA FILHO, Olavo P. Carnaúba, Pedra e Barro na capitania de São José do Piauhy. Belo Horizonte: Ed. Do Autor, 2007, p.105.

Estamos, portanto, perante a uma notável realização citadina que obedeceu a um plano ordenado para sua forma, mas que não fluiu por si só e sim pelas forças das circunstâncias políticosociais local e nacional. É preciso, contudo, sublinhar que na “cidade de Saraiva” havia uma preocupação estética, que se submeteu exclusivamente às leis de uma geometria "natural”, e outra retilínea, que extraída duma temporalidade concreta tornou-se processo. Além disso, estimulou a implantação da navegação a vapor no rio Parnaíba e exerceu forte influência nos surgimentos e ressurgimentos das vilas/cidade beira-rio Parnaíba. Esta cidade foi concebida e é destinada a servir de complemento a municípios antigos ou recentes, cujo núcleo central está solidamente implantado.

Teresina, então, representou/representa a síntese das propostas políticas, econômica e sociocultural que promoveria/promoveu/promove o desenvolvimento do Estado do Piauí. Representou, também, um tempo novo que se estruturava nos horizontes do vale. Representou, acima de tudo, a esperança que segundo Coelho (2002, p.07) “[...] esperança daquilo que não é, não existe, mas pode vir a ser [...]”. Representava e expressava o "progresso” e a “modernidade”. Ela corresponde ao momento da realização de uma intenção e possui, sobretudo, um valor simbólico. Em lugar de ser obra da engenharia, a cidade capital Teresina é sob duas formas, teórica e prática em seu nascedouro, apanágio político. Constituiu-se ali toda uma complexa tecnoestrutura governamental, voltada para os problemas econômicos do Estado e, conseqüentemente, do país, 
que bem pode ser encarada como a manifestação de um novo estágio, no processo de amadurecimento do estado capitalista. Como já dissemos esta cidade surgiu como um elemento de estratégia político-econômica, mas, talvez, pela primeira vez, na História do Brasil, uma cidade capital, surgia planejada e construída em função de uma estrada líquida e como elemento estratégico do "progresso".

O resultado de tudo isso foi uma "nova cidade capital" onde seu princípio seria aplicado com rigor consciente e proposital na sua forma para ganhar, dinamismo, luz, brilho, enfim, vida. Parafraseando Lepetit (2001), as condições históricas que a fizeram nascer favoreciam tal procedimento. Em verdade, a necessidade que provocou seu surgimento podia ser nova, particular à sua época, mas ela foi o resultado preciso e espontâneo de uma estrita concepção da época, da adaptação mais lógica ao que ela devia ser para responder ao uso mais prático do que dela se esperava. Teresina seguiu sua trajetória, no tempo e no espaço, aos traços mais significativos de ordenamento que se perpetuou/perpetua desde a aurora de seu surgimento até aqui na primeira década século XXI. O resultado alcançado poderia/poderá não satisfazer a todos os gostos, mas é preciso reconhecer que correspondeu plenamente à intenção manifestada.

Lá se vai o rio Parnaíba, o típico perfil da paisagem... e o belo horizonte piauiense ganhou para eternizar-se o corpo edificado da sonhada cidade capital. Teresina é, por essência, o terreno de uma fundação. A ordem específica dessa cidade se expressa com uma precisão de detalhes e uma regularidade que eliminam a possibilidade de variantes. Na raiz de qualquer cidade ou no íntimo dos que pretendem fundá-las, em verdade, escondem-se tendências, sistemas de valores e certo desenraizamento. Sabemos que a cidade, em seu sonho desperto, aumenta a profundidade e a intensidade potenciais da experiência humana que nesse tal desenraizamento, fenômeno preparado em longo prazo, se manifesta à luz da história para dar fim a um espetáculo. A cidade de Teresina é o produto cultural da sociedade, na qual a fragilidade do quadro da vida se acentua.

Particularmente pensamos que a assimilação do passado e a efetivação de um futuro foram os dois polos onipresentes na existência daquela sociedade, na medida em que apreciou o futuro como potencialidade, possibilidade, modernidade. Nas suas linhas divisórias e nos seus contornos, na fixação, na utilização do sitio natural, a cidade registra a história piauiense que se evidencia diante dos fenômenos fundamentais da sua existência. Sabemos que as cidades nascem ou são fundadas segundo a representação adequada a uma dominação política, econômica, religiosa ou militar. Destarte, a cidade de Teresina foi fruto de interesses políticos e econômicos, ao reivindicarem a modernidade e o desenvolvimento para o Estado do Piauí. Essa cidade nos fornece traços de um projeto moderno em sua morfologia, capazes de expressar os anseios explicitados nos 
discursos do progresso. O transporte é um dos pilares do seu nascedouro e contribui para a formação do padrão específico da vida citadina. Essa tendência fez sua inscrição no processo de “expansão”, de “modernização”, de “modernidade”, de “progresso”, enfim em sua dimensão histórica.

E Oeiras? O “fracasso" de Oeiras é sempre explicado pelo caráter limitador de sua localidade e organização. Ela resultou de um complexo histórico com sua herança de “inconveniências” e moveu-se lentamente em direção a um destino condicionado, mas incerto, o futuro. Os princípios de sua geometria rígida provinda do meio mais simples e mais rápido com uma relativa adaptação ao relevo se impuseram desde cedo em preocupação maior. Aquelas técnicas avançadas de transporte e comunicação que dão sentido à expansão foram decisivos para sua morbidade. À parte da lucidez de sua localidade e do traçado extraordinário alcançado por sua obra construída aos moldes rurais está em sua mentalidade aforística e dialética a importância que atribuíam às polaridades, mobilidade/imobilidade. Destarte havia, por acaso ou consonância, alguma referência ao esquecimento. Mas uma cidade assim lenta, que levava ao esquecimento, desafiou o próprio tempo, pois a sua forma colocou-se, de imediato, na categoria das formas eternas. Sua materialidade é marcada pela ação contínua do tempo, e o seu inventário inscreve-se quase inteiro na História do Brasil. Os choques que lhe foram deferidos produziram-lhe resultados sociais e as necessidades tomaram a forma de ideais e invenções que levaram a comunidade oeirense a seguir por novos canais de experiência.

A atual cidade Oeiras trata-se de uma sobrevivência de caráter histórico, que não correspondeu às necessidades da unidade que ela encabeçava, mas é, por si mesma, depositária de história. Ela é o próprio texto da história colonial da sociedade piauiense. E foi, talvez, por esta razão, que Oeiras pôde correr nas águas do esquecimento, enquanto Teresina se abrigava nas águas da esperança. Em uma palavra, Oeiras é a raiz e Teresina a flor resultante de toda a história. Esta foi uma das performances encontrada nos discursos mudancistas e na efetivação da transferência da capital. E podemos adiantar que os discursos de outrora são dignos de fascinação. Por tudo isso, entendemos, assim como Bernard Lepetit, “[...] que o conhecimento histórico progride não tanto para resolver os problemas quanto por modificar a forma de colocá-los”. (LEPETIT, 2011, p.59).

\section{Notas}

${ }^{1}$ Os resultados aqui apresentados são parte das pesquisas efetuadas por Gercinair Silvério Gandara que resultou na Tese de Doutorado intitulada Rio Parnaíba... Cidades-Beira. (1850-1950). Brasília, UnB, 2008. Orientada pela Profa. Dra. Vanessa M. Brasil.

${ }^{2}$ Ver GANDARA, Gercinair S. Rio Parnaíba... Cidades-Beira. Brasília:UnB, 2008. 
${ }^{3}$ Em nossa dissertação de mestrado fizemos uma reflexão que resultou no alargamento dos conceitos de fronteira. Ver GANDARA, op. cit. nota 29. Ver também AUBERTIN, Catherine. (org.) Fronteiras. Bertha Becher...et al. . Brasília: UNB, 1988, BARTH, FREDRICK. Grupos Étnicos e Suas Fronteiras (trad. Élcio Fernandes) SP: UNESP, 1998 e MARTINS, José de Souza. O tempo da Fronteira: retorno à controvérsia sobre o tempo histórico da frente de expansão e da frente pioneira. Tempo Social; Rev. Sociologia, USP, São Paulo, 8(1):25-70, May, 1996.

${ }^{4}$ Ofício de 08.04.1798 dirigido ao Ministro de Ultramar D. Rodrigo de Sousa Coutinho.

${ }^{5}$ Oficio de 19.08.1798.

${ }^{6}$ Ver GANDARA, Gercinair Silvério. Rio Parnaíba... Cidades-Beira. (1850-1950) Tese de Doutorado Brasília, UnB, 2008.

${ }^{7}$ Lei $n^{\circ} .174$ de 27.08.1844.

${ }^{8}$ Tenho dado a razão porque não foi aquela lei executada por meu antecessor, não há de ser por mim, nem também, segundo todas as probabilidades pelos meus sucessores. Construir todos os edifícios necessários ao serviço, erguer de repente uma cidade inteira, é empresa possível a um homem de gênio, que disponha de inumeráveis braços e de uma riqueza imensa, mas é perfeita quimera para o governo constitucional de uma província pobre. (Relatório de 01.08.1845. Zacarias de Góes e Vasconcelos)

9 “[...] Muito se tem falado em um plano de mudança da Capital, mas pelo que vou observando, parece-me inexeqüível, ou pelo menos muito dispendioso do que a navegação...”. (Ofício de 02.11.1847)

${ }^{10}$ Datada de 23.08.1849.

${ }^{11}$ Resolução Provincial n ${ }^{\circ}$. 255 de 05.08.1850 sancionada pelo Presidente Inácio Francisco Saraiva da Mata

${ }^{12}$ As reflexões relativas à representação da modernidade são fecundas e perfazem um longo caminho nem sempre pautado por vias consensuais. Para Renato Ortiz (1990),“[...] modernidade, modernismo, modernização, são temas que sempre estiveram entre nós, de alguma forma associados a questão nacional”. Ver ORTIZ, Renato. Advento da Modernidade. LUA NOVA: Cultura e Modernidade. Revista de Cultura e Política. Maio/1990 nº. 20, p.13

13 José Antonio Saraiva presidiu a Província do Piauí de 1850 a 1853.

${ }^{14}$ Relatório de 20.12.1850. De José Antônio Saraiva ao Conselheiro do Estado Visconde de Monte Alegre, Ministro e Secretário de Estado dos Negócios do Império.

${ }^{15}$ Neste Memorial para acolher a nova capital sugeriam a cidade de Parnaíba apontando seus recursos naturais e outros elementos de vida e prosperidade. Mas, como alternativa enfatizava que no caso de não ser possível a escolha daquela, indicavam a Vila Nova do Poti, pela sua vantajosa situação à margem do rio Parnaíba e outras vantagens de fácil compreensão.

${ }^{16}$ Aonde chegou em 18.11.1850.

17 “Chegando a Vila Velha do Poti, fácil me foi compreender que, sujeita a febres endêmicas, seria arruinada pelas enchentes daquele rio, não podia aquela vila florescer, e que seus habitantes desejavam com ansiedade edificá-la em qualquer outro lugar que pudesse convir aos seus interesses”. Fala à Assembleia provincial de 03.07.1851

${ }^{18}$ Neste ofício demonstrou que intencionava pedir à Assembleia a mudança da Vila para a margem do rio Parnaíba e, para tanto, a Matriz deveria ser lá edificada preconizando que “[...] a navegação do Parnaíba um pouco mais desenvolvida operaria a sua mudança [...] essas poucas casas que ali existem se mudarão para a beira do rio sem qualquer aumento da navegação. (Ofício de 20.12.1850). Lembrando a Lei datada de 23.08.1849 que autorizava a mudança da capital para esta localidade, “[...] essa esplanada já tinha sido designada por uma lei para assento de uma povoação que recebesse a Capital da Província, lei que nunca teve um meio de execução, e que foi pouco depois revogada porque nasceu antes do tempo". E justificou “[...] foi redigida antes de haverem estudado os meios convenientes e adequados a resolver a questão da mudança da Capital...”.

${ }^{19}$ Por meio da Lei ${ }^{\circ} 140$ de 29.11.1842

${ }^{20}$ Sobre o processo da transferência, implantação da capital e a construção da cidade de Teresina ver Odilon Nunes (1974), CHAVES (1987) e GANDARA (2008).

${ }^{21}$ No dia 24.12.1852 fez-se a benção solene do santuário bem como a translação, em solene procissão, da imagem da padroeira da velha igreja do Poti para a de Teresina, em construção. No dia seguinte, verificou-se a inauguração da capela-mor da igreja de Nossa Senhora do Amparo, com a celebração de sua primeira missa. No ano seguinte se verificou a transferência da sede da Paróquia como previu o presidente Saraiva.

${ }^{22}$ Utilizamos aqui a expressão bandeirante tal qual se cristalizou em RICARDO (1959)

${ }^{23}$ Evidenciamos que a escolha de um lugar estratégico com condições necessárias para a criação de uma cidade é característica de outras localidades e, também, são relatados em obras literárias. Ver em GANDARA (2004).

${ }^{24}$ Assembleia Provincial de 03.07.1851

${ }^{25}$ No Ofício de 20.12.1850 dirigido ao conselheiro Visconde de Monte Alegre

${ }^{26}$ Fala com a qual instalou a Assembleia Provincial de 03.07.1851.

27 "Na medida em que se consolida o 'poder pessoal' do Imperador, depois de 1840, sobretudo a partir do Conselho de Estado, revigorados os laços de dependência das províncias extremas com o centro, principalmente graças ao deslocamento do poder decisório para o novo eixo de gravidade econômica do país. Começa a tarefa centralizadora, cai o Visconde da Parnaíba, vindo o representante do centro no instante mesmo em que o Governo tende a valer-se do 
comércio externo. Daí porque a navegação fluvial e marítima, o problema do porto tornar-se-iam temas centrais, e se pensa decisivamente na mudança da capital”. SANTANA, Monteiro R.N. Perspectiva Histórica do Piauí. Teresina: Ed. Cultura, 1965, p. 30).

${ }^{28}$ Nasceu a 1.03.1823, na freguesia Bom Jardim, município de Santo Amaro, Província da Bahia. Bacharel em Direito pela Faculdade de São Paulo. Desempenhou os cargos de Juiz Municipal e de Procurador Fiscal da Fazenda em sua terra natal. Iniciou-se na vida política como deputado provincial, sob a chefia do Marquês de Olinda. Foi nomeado presidente da província aos 27 anos de idade.

${ }^{29}$ Ver esta fala transcrita na íntegra em CHAVES, op. cit., nota 117.

${ }^{30}$ Em 01.07.1852.

${ }^{31}$ Para a literatura local este nome foi dado em homenagem à imperatriz do Brasil, D. Teresa Cristina..

${ }^{32}$ Estribado na Lei ${ }^{\circ} 140$ de1842.

${ }^{33}$ Data da Lei Provincial n 393 que criou a comarca de Teresina, desmembrando de São Gonçalo, hoje Regeneração, o seu termo judiciário.

34 “Tenho a honra de comunicar a V. Excia que o corpo legislativo provincial autorizou pela Lei no. 315, de 21 de julho do corrente ano, a transferir a capital desta Província para a nova cidade de Teresina, e que dei já execução a essa lei, pelo que me acho residindo nesta cidade à disposição de V.Excia..

${ }^{35}$ Datada de 21.10.1852.

36 “Comunico a V. Excia que esta Província está em paz, e que se acha completamente transferida para esta cidade de Teresina a capital da Província e funcionando regularmente todas as repartições públicas”. Ver Relatório de 11.03.1853 de José Antonio Saraiva ao sucessor Simplício de Sousa Mendes. Arquivo Público do Piauí. Teresina-PI.

${ }^{37}$ Pela Resolução 315.

${ }^{38}$ Ver Chaves, 1987.

\section{Referências}

BONFIM, W. L.; SANTOS JÚNIOR, R. B. Formação Política. In PIAUÍ: Formação, Desenvolvimento, Perspectivas. R. N. Monteiro de Santana. (Org.). Teresina: Halley, 1995.

BRUAND, Y. Arquitetura contemporânea no Brasil. São Paulo, Perspectiva, 2002.

CASAL, M. A. (1754-1821) Chorographia Brazilica, 1818.

COELHO, M. A. T. Rio das Velhas: memórias e desafios. São Paulo: Paz e Terra, 2002.

CHAVES, J. Como Nasceu Teresina. $2^{\circ}$ ed. Teresina: PMT/Fundação Cultural, 1987.

FERREIRA, J. P. Enciclopédia dos Municípios Brasileiros. Cidades Piauí Conselhos Nacional de Geografia e Nacional de Estatística. Janeiro de 1958.

FRANCO, J. P. O Município no Piauí. 1761-1961. Ed comemorativa dos 125 anos da fundação de Teresina. Teresina, 1961.

GAMEIRO, Alvina . A vela e o Temporal. Rio de Janeiro: O Cruzeiro,1957.

GANDARA, Gercinair Silvério. Rio Parnaíba... Cidades-Beira. 2008. Tese ( Doutorado em História). Brasília: UnB, 2008.

GANDARA, Gercinair Silvério. Uruaçu: Cidade-Beira, Cidade-Fronteira (1910-1960) Goiânia: Mestrado em História/UFG, 2004.

LA BLACHE, Vidal de. P. Principios de Geografía Humana. Lisboa: Cosmos, 1954.

LEPETIT B.; PUMAIN D. Le temps des Ville. In. Temporalités Urbaines. org Paris: 
Antropos, 2000.

LE GOFF, J. História e Memória. 2ª ed. Trad. Bernardo Leitão. Campinas: UNICAMP, 1992.

MARX, Murilo. In Cidade brasileira. São Paulo, Melhoramento/Edusp, 1980.

MELO, P. C. Duas Capitais. In PIAUÍ: Formação. Desenvolvimento. Perspectivas. R. N.

Monteiro de Santana. (Org.). Teresina: Halley, 1995.

MENDES, F. Formação Econômica. In PIAUÍ: Formação. Desenvolvimento. Perspectivas. R. N. Monteiro de Santana. (Org.). Teresina: Halley, 1995.

MUMFORD, Levis. A Cultura das Cidades. Trad. Neil R. da Silva, Ed. Belo Horizonte: Itatiaia, 1961.

NUNES, M. C. P.; ABREU, I. G. Vilas e Cidades do Piauí. In PIAUÍ: Formação.

Desenvolvimento. Perspectivas. R. N. Monteiro de Santana. (Org.). Teresina: Halley, 1995.

NUNES, Odilon. Pesquisas para a História do Piauí. Vol. I, II, III Teresina. Imprensa Oficial do Estado do Piauí, 1966.

do Piauí, 1974.

Pesquisas para a História do Piauí. Vol. IV. Teresina. Imprensa Oficial do Estado

RICARDO, CASSIANO. Marcha para Oeste (A Influência da "Bandeira” na formação social e política do Brasil) 3ª ed. Vol. I e II. Rio de Janeiro: José Olympio, 1959.

ROSSI, A. A arquitetura da Cidade. São Paulo: Martins Fontes, 1995.

SANTANA, Raimundo Nonato Monteiro de. Perspectiva Histórica do Piauí. Teresina: Ed. Cultura, 1965.

SILVA FILHO, O. P. S. F. Carnaúba , pedra e barro na Capitania de São José do Piauhy. Belo Horizonte: Ed. Do Autor, 2007.

SPIX E MARTIUS. Viagem pelo Brasil (1817-1820). TOMO II Vol. II. $3^{\mathrm{a}}$ ed. Trad. Lucia Furquim Lahmeyer e Basílio de Magalhães. São Paulo: Melhoramentos, 1976.

VIDAL, L. De Nova Lisboa a Brasília: a invenção de uma capital. Brasília: ed. UnB, 2009.

Recebido em: 15/02/2011

Aprovado em: 20/04/2011 